\title{
Abundance and Diversity of Arbuscular Mycorrhizal Fungi in a Soil Polluted by Mining Activities in Lubumbashi (Haut-Katanga, D.R. Congo)
}

\author{
Mashagiro Grace Queen ${ }^{1,2 *}$, Muganguzi Ntale Trésor ${ }^{1,2}$, Kisimba Ngobola Trésor ${ }^{1,2,4}$, Mavungu
} Muzulukwau Judith ${ }^{3}$, Tshibangu Kazadi Audry ${ }^{3}$

${ }^{I}$ Department of Natural and Renewable Resources Management, Faculty of Agronomic Sciences, University of Lubumbashi, PO Box 1825, Lubumbashi, D.R. Congo

${ }^{2}$ Biogeochemistry, Ecology of Soils and Tropical Ecosystems (BESET) Research Unit, Faculty of Agronomic Sciences, University of Lubumbashi, PO Box 1825, Lubumbashi, D.R. Congo

${ }^{3}$ Plant Production Systems Research Unit, Department of Crops Sciences, Faculty of Agronomy, University of Lubumbashi, PO Box 1825, PO Box 1825, Lubumbashi, D.R. Congo

${ }^{4}$ Agro-Pedological Laboratory, Faculty of Agronomic Sciences, University of Lubumbashi, PO Box 1825, Lubumbashi, D.R. Congo

*Corresponding Authors: Mashagiro Grace Queen, Department of Natural and Renewable Resources Management, Faculty of Agronomic Sciences, University of Lubumbashi, PO Box 1825, Lubumbashi, D.R. Congo

\begin{abstract}
Mining activities negatively influence the activity of soil fauna in general. However, the thorough response of arbuscular mycorrhizal fungi $(A M F)$ to mining activities in the Lubumbashi region is not yet well understood. This study was undertaken with the objective of assessing the influence of mining activity on mycorrhizal status, under two different ecosystems (forest and savannah), around a tailing pond (TP). The physico-chemical and biological analyzes focused on composite soil samples collected at regular intervals of $200 \mathrm{~m}$ along four transects (including two in each of the two ecosystems) starting from the edges of TP. The results showed high $\mathrm{Fe}, \mathrm{Cu}, \mathrm{Mn}$ and Ba concentrations near TP in both ecosystems. The abundance of different AMF species, such as organic matter (OM) concentrations, increased according to the distance to the TP in both ecosystems, indicating a harmful effect of mining activities on AMF and OM concentration subsequently. Three AMF species including Acaulospora lacunosa, Archaospora schenkii and Acaulospora scrobiculata have been identified on the site, thus demonstrating a crucial interest in restoring soils polluted by mining activities.
\end{abstract}

Keywords: Mining activities, Heavy metals, arbuscular mycorrhizal fungi, Tailing pond, Lubumbashi

\section{INTRODUCTION}

The soil of the natural or managed ecosystem is a critical and dynamic part of the three-dimensional regulatory system which generates a multitude of functions, also called "soil functions". These functions support the provision of ecosystem services (Blum, 2005). Soil is one of the most complex biomaterials in the world and a key component of the earth's ecosystem operating at the interface of the lithosphere, hydrosphere, biosphere and atmosphere (Young and Crowford, 2004). We have substantial knowledge of soils, their formations and their distribution, but our understanding of its functions and ecosystem services is incomplete. Indeed, this one remains a pool of plant nutrients and a habitat for numerous living organisms (Lehman and Kleber, 2015), including microorganisms (Ouédraogo et al., 2017; Xu et al., 2019) which provide several functions.

In general, microorganisms play a key role in nutrient recycling, facilitating chemical processes, decomposing organic matter and improving crop yields (Konaté et al., 2003; Ouédraogo et al., 2005; Lavelle et al., 2006; Pey, 2010; Doamba et al., 2011). Particularly, the arbuscular mycorrhizal fungi (AMF), belonging to the phylum Glomeromycota (Schüßler et al., 2001), live in symbiosis with several terrestrial plants (Smith and Read, 2008; Pellegrino and Bedini, 2014). It has already been clearly established that mycorrhizal plants take up water and mineral nutrients, particularly phosphorus $(\mathrm{P})$, in an efficient manner than non-mycorrhizal plants (Thirkell et al., 2016). Furthermore, various studies 
have reported that AMF protect plants against various biotic and abiotic stresses (Doubková et al., 2012; Lehmann et al., 2014; Cabral et al., 2015). Though, these symbiotic functions are diversified at the level of AMF species, host plants, soil properties and even at the level of AMF ecotypes (Hildebrandt et al., 2007; Hempel et al., 2009; Zarei et al., 2010). The distribution of AMF is also led by several environmental factors, including nutrients (such as P), soil texture, soil pH, etc. (Cheng et al., 2013; Moebius-Clune et al., 2013). Therefore, any environmental change negatively impacting their activities, would seriously affect several ecosystem functions (Wang et al., 2010).

Moreover, soil pollution by heavy metals is thus a serious and widespread problem. This is much more the result of anthropogenic activities, in particular, mining activity (Margesin et al., 2011; Yang et al., 2015; Gómez-Sagasti et al., 2012). Indeed, it has been noticed in the city of Lubumbashi (Haut-Katanga province, D.R Congo), as in several countries of the world, a development of the mining sector (Tembo et al., 2005; Ngoy et al., 2010), leading to releases into the environment of huge quantities of heavy metal-laden waste (Gremion et al., 2004; Mpundu et al., 2013a, 2013b). Beyond their toxicity (Hall, 2002; Hassan et al., 2011), the dangerous nature of these metal pollutants is that they are not biodegradable like organic pollutants (Yang et al., 2015; Tembo et al., 2005) and therefore, they persist in the environment (Bolan et al. 2014). The impacts of the heavy metals soil accumulation, on living organisms have already been demonstrated by various studies around the world (Xing et al., 2015), including various effects on microbial biomass, diversity and activities (Alguacil et al., 2011; Margesin et al., 2011). In the city of Lubumbashi, although various studies have highlighted the danger of mining pollution on plants and humans (Mbenza et al., 1989; Lubalega et al., 2015; Katemo et al., 2010; Mpundu et al., 2013a, 2013b), there remains a poor knowledge about its effects on soil microorganisms, particularly on AMF. Hence, the objective of this study was to assess the influence of mining activity on the mycorrhizal status (abundance and diversity), under two different ecosystems (forest and savannah), around the MMG/Kinsevere tailing pond (TP), a site under the influence of mining activity around Lubumbashi.

\section{Materials AND MethodS}

\subsection{Study Area}

The study area is located around the TP of the MMG/Kinsevere mining company, in the vicinity of the

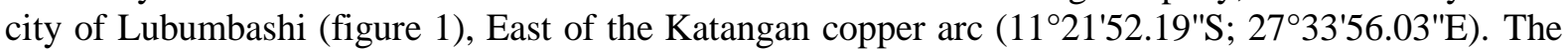
study region, like that of Lubumbashi, is characterized by an alternation of two seasons, including a rainy season (from November to March) with an annual average rainfall of $1200 \mathrm{~mm}$ and a dry season (from May to September), with April and October as the transition months (Vranken, 2010). The study area soils, referring to Ngongo et al. (2009), are lithosol type on the plateau (10 cm deep), regosols on slope colluvium $(15 \mathrm{~cm})$, very shallow ferralsols on lateritic breastplate with a break in slope (50 to 100 $\mathrm{cm})$ and ferralsols deep in the poisoning halo.

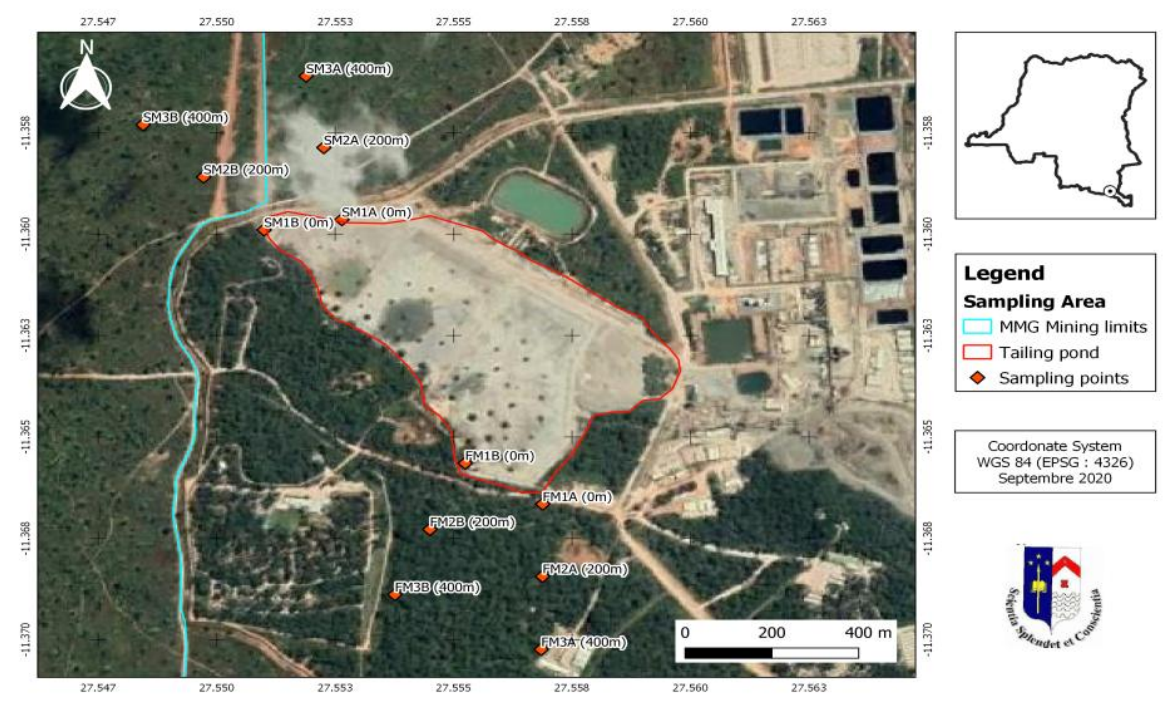

Figure1. Mapping of the study area (MMG/Kinsevere mine) and sampling points in both ecosystems (forest and savannah) around TP. 


\subsection{Soil sampling}

Sampling was carried out during the end of the rainy season (month of March) in 2017, following the grid system developed by Huising et al. (2012). Twelve samples were collected in two different ecosystems (forest and savannah), at regular intervals of $200 \mathrm{~m}$, on two transects in each of the ecosystems whose origin was chosen at random at the edge of the TP up to $400 \mathrm{~m}$. With a specially adapted soil probe $(5 \times 20 \mathrm{~cm})$, five soil cores were collected from the first $20 \mathrm{~cm}$ of deepness, including one core in each corner of the quadra and one in the center, thus forming a composite sample (Vannier and Vidal, 1964) in order to obtain a representative sample from the sampling point (figure 2). After collection, the composite samples were packaged in zip-top plastic bags and labelled. Those planned for microbiological analysis were stored in a cooler with ice to prevent desiccation (Huising et al., 2012). These were then stored at $4^{\circ} \mathrm{C}$ before spore extraction, as recommended by Wang et al. (2007) and Zhang et al. (20016).

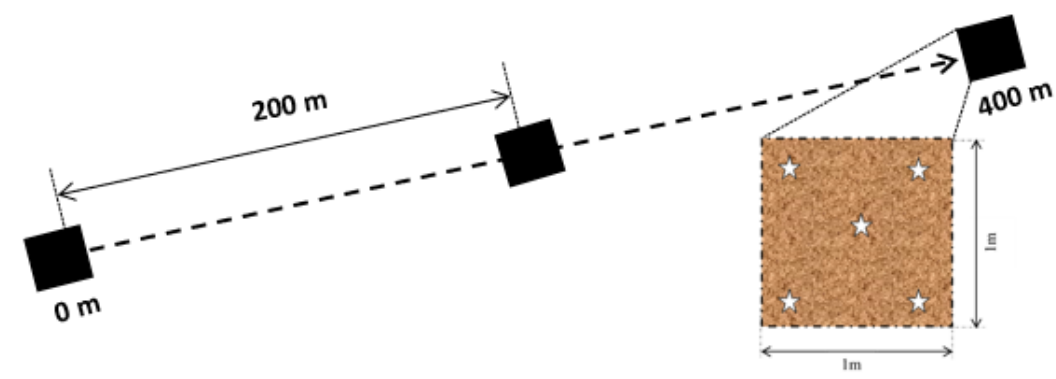

Figure2. Soil sampling strategy

\subsection{Physico-chemical analysis of soils}

Soil samples were dried, before being crushed and then sieved at $2 \mathrm{~mm}$ mesh. The physico-chemical analyzes were performed on less than $2 \mathrm{~mm}$ soil fraction, at the agro-pedological laboratory of the faculty of agronomic sciences, University of Lubumbashi (FSA/UNILU). Soil pH was determined using the potentiometer method (Van Ranst et al., 1999). Total nitrogen (N tot) was determined according to the Kjeldhal method (Bremner and Mulvaney, 1982; Van Ranst et al., 1999). Organic matter (OM) was calculated based on organic carbon determined according to the Walkley and Black method (Van Ranst et al., 1999). The exchangeable acidity $\left(\mathrm{H}^{+}+\mathrm{Al}^{3+}\right)$ was determined by titrimetry described by Van Ranst et al. (1999). The cation exchange capacity (CEC) was determined according to the adsorption and desorption method described by Van Ranst et al. (1999). Exchangeable bases $\left(\mathrm{Ca}^{2+}, \mathrm{Mg}^{2+}, \mathrm{K}^{+}, \mathrm{Na}^{+}\right)$ were determined by flame spectrophotometry, according to the method described by Van Ranst et al. (1999). Total concentrations of $\mathrm{K}, \mathrm{Fe}, \mathrm{Ti}, \mathrm{Cu}, \mathrm{Mn}, \mathrm{Rb}$ and $\mathrm{Ba}$ were determined using X-ray fluorescence analyser (XRF; Yoshimura et al., 2002; Samia, 2013; Paulette et al., 2015).

\subsection{Extraction and description of AMF spores}

Microbiological analyzes were carried out in the mycorrhizal laboratory of FSA/UNILU. For each sample, $100 \mathrm{~g}$ soil was weighed and then allowed to stand in water in plastic beakers for 20 minutes. The rested solution was then passed through superimposed sieves of $1 \mathrm{~mm}$ and $45 \mu \mathrm{m}$ of mesh in order to eliminate the large particles and the sol collected on $45 \mu \mathrm{m}$ was put in $50 \mathrm{ml}$ plastic tubes for a first centrifugation for 10 minutes at 2000 revolutions per minute. The obtained supernatant was poured in and replaced with a $25 \%$ sucrose solution which was mixed and then centrifuged a second time for 2000 revolutions per minute for 10 minutes and the obtained supernatant was filtered through the $45 \mu \mathrm{m}$ sieve. This second centrifugation allowed us to recover the spores washed with water on the $45 \mu \mathrm{m}$ sieve and collect them using a squeeze bottle then put them in Petri dishes to proceed to observation with a 40X binocular. Spores were counted and described by size, shape, color, presence or absence of pedicels (Walker et al. 2006).

\subsection{Statistical processing}

Raw data on chemical and biological parameters encoded on an Excel sheet (2016). Means, standard deviations and graphs were produced using MS Excel software (2016). The different diversity indices were determined using PAST software (version 3). 


\section{RESUltS}

\subsection{Characterization of soils around the MMG/Kinsevere tailing pond}

It results from the chemical analyzes (table 1 ) that the values of $\mathrm{pH}-\mathrm{H}_{2} \mathrm{O}$ decrease substantially between $0 \mathrm{~m}$ and $200 \mathrm{~m}$ and increase towards $400 \mathrm{~m}$; so, in the forest as in the savannah, very low $\mathrm{pH}-\mathrm{H}_{2} \mathrm{O}$ values (very acidic $\mathrm{pH}$ ) were observed at $200 \mathrm{~m}$ from TP (4.99 in the forest as in the savannah). Though, the $\mathrm{pH}-\mathrm{KCl}$ values decrease following the distance to TP; thus, in both ecosystems, the low values were observed at $400 \mathrm{~m}$ far from the TP (4.1 and 3.98 respectively in the forest and in the savannah). Means values show that the soils of these two ecosystems present moderately acidic $\mathrm{pH}$ (respectively, 5.3 \pm 0.3 and 5.12 \pm 0.2 in the forest and in the savannah) with a very low value observed in the savannah. Overall, the OM concentrations increase with the distance from TP (table 1); therefore, the high OM concentrations are observed at $400 \mathrm{~m}$ in both ecosystems. In comparison, the forest presented a high OM concentration $(1.47 \pm 0.5 \%)$ than the savannah $(1.35 \pm 0.7 \%)$.

Furthermore, $\mathrm{N}$ tot contents remain almost constant following the distance to TP in the forest as in the savannah (table 1); but, a slight negligible difference was observed from point to point; low values are observed at $0 \mathrm{~m}$ and $200 \mathrm{~m}(0.06 \%)$ in the forest and at $0 \mathrm{~m}(0.04 \%)$ in the savannah. The exchangeable acidity decreases with distance from TP depending on whether it is forest or savannah; thus, low values were observed at $400 \mathrm{~m}$ from TP. The CEC increases with distance to TP in the forest while this one decreases in the savannah.

Regarding the exchangeable bases, the $\mathrm{K}^{+}$and $\mathrm{Na}^{+}$contents increase according to the distance from $\mathrm{TP}$ in the forest as in the savannah; thus, low values were observed at $0 \mathrm{~m}$, while high values were observed at $400 \mathrm{~m}$. However, this trend is not observed for $\mathrm{Ca}^{2+}$ and $\mathrm{Mg}^{2+}$ contents. Thus, in the forest, the high $\mathrm{Ca}^{2+}$ concentrations were observed at $200 \mathrm{~m}$ from TP, while in the savannah, the low concentrations were observed at the same distance. As for $\mathrm{Mg}^{2+}$; low concentrations were observed at $0 \mathrm{~m}$ in the forest, but at $200 \mathrm{~m}$ in the savannah.

$\mathrm{K}$ tot analysis reveals varying levels depending on the distance from TP. Thus, total $\mathrm{K}$ contents increase according to the distance from TP in the forest (with a high concentration observed at $400 \mathrm{~m}$ ), while they decrease in the savannah (with a high concentration at $0 \mathrm{~m}$ ). Comparing ecosystems and TP, high concentrations $(2.3 \pm 0.6 \%)$ were observed in the forest, followed by the center of TP $(2.23 \%)$, while low concentrations $(1.52 \pm 0.4 \%)$ were observed in the savannah. Regarding to the total heavy metal contents, it was noticed that the total $\mathrm{Fe}, \mathrm{Cu}, \mathrm{Mn}$ and $\mathrm{Ba}$ concentrations decrease according to the distance to TP in the forest as in the savannah, with the low grades observed at $400 \mathrm{~m}$ from TP (table 1). The center of TP presented strongly elevated $\mathrm{Cu}$ concentrations than that observed respectively in both ecosystems. In addition, the total Ti concentrations increase slightly in the forest from $0 \mathrm{~m}$ to 200 $\mathrm{m}$, but remain constant from $200 \mathrm{~m}$ to $400 \mathrm{~m}$; however, these decrease slightly depending on the distance from TP in the savannah. Concerning Rb, the concentrations decrease according to the distance from TP in the forest, but they increase slightly from $0 \mathrm{~m}$ to $200 \mathrm{~m}$ and decrease appreciably towards $400 \mathrm{~m}$ in the savannah (table 1).

Table1. Physicochemical properties of soils at different sampling points around TP at MMG / Kinsevere

\begin{tabular}{|c|c|c|c|c|c|c|c|c|c|}
\hline & \multicolumn{3}{|l|}{ Forest } & \multicolumn{3}{|l|}{ Savannah } & \multirow{2}{*}{$\begin{array}{l}\text { Mean in } \\
\text { Forest }\end{array}$} & \multirow{2}{*}{\begin{tabular}{|l|} 
Mean in \\
Savanna \\
h
\end{tabular}} & \multirow{2}{*}{$\begin{array}{l}\text { Mea } \\
n \quad \text { in } \\
T P\end{array}$} \\
\hline & $0 \mathrm{~m}$ & $200 \mathrm{~m}$ & $400 \mathrm{~m}$ & $0 \mathrm{~m}$ & $200 \mathrm{~m}$ & $400 \mathrm{~m}$ & & & \\
\hline $\mathrm{pH} \mathrm{H}_{2} \mathrm{O}$ & $5.48 \pm 0.1$ & $\begin{array}{l}4.99 \pm 0 . \\
0\end{array}$ & $\begin{array}{l}5.44 \pm 0 . \\
5\end{array}$ & $5.24 \pm 0.3$ & $\begin{array}{l}4.99 \pm 0 . \\
1\end{array}$ & \begin{tabular}{|l|}
$5.17 \pm$ \\
0.0
\end{tabular} & $5.3 \pm 0.3$ & $5.12 \pm 0.2$ & - \\
\hline pH KCl & $5.33 \pm 0.2$ & $4.4 \pm 0.0$ & $4.1 \pm 0.2$ & $4.46 \pm 0.4$ & $\begin{array}{l}4.42 \pm 0 . \\
5\end{array}$ & \begin{tabular}{|l|}
$3.98 \pm$ \\
0.0 \\
\end{tabular} & $4.61 \pm 0.6$ & $4.35 \pm 0.4$ & - \\
\hline OM (\%) & $1.25 \pm 0.2$ & $\begin{array}{l}1.39 \pm 0 . \\
9\end{array}$ & $\begin{array}{l}1.78 \pm 0 . \\
0\end{array}$ & $0.69 \pm 0.6$ & $\begin{array}{l}1.78 \pm 0 . \\
6\end{array}$ & \begin{tabular}{|l|}
$1.83 \pm$ \\
0.0
\end{tabular} & $1.47 \pm 0.5$ & $1.35 \pm 0.7$ & - \\
\hline $\mathrm{N}$ tot $(\%)$ & $0.06 \pm 0.0$ & $\begin{array}{l}0.06 \pm 0 . \\
0\end{array}$ & $\begin{array}{l}0.09 \pm 0 . \\
0\end{array}$ & $0.04 \pm 0.0$ & \begin{tabular}{|l|}
$0.08 \pm 0$. \\
0 \\
\end{tabular} & \begin{tabular}{|l|}
$0.07 \pm$ \\
0.0
\end{tabular} & $0.07 \pm 0.0$ & $0.06 \pm 0.0$ & - \\
\hline $\begin{array}{l}\mathrm{H}^{+}+\mathrm{Al}^{3+} \\
(\mathrm{méq} / \mathbf{1 0 0 g})\end{array}$ & $1.66 \pm 1.2$ & $\begin{array}{l}1.26 \pm 0 . \\
3\end{array}$ & $\begin{array}{l}0.86 \pm 0 . \\
9\end{array}$ & $1.62 \pm 0.7$ & $\begin{array}{l}1.42 \pm 0 \\
0 \\
\end{array}$ & \begin{tabular}{|l|}
$0.30 \pm$ \\
0.0 \\
\end{tabular} & $1.26 \pm 0.8$ & $1.28 \pm 0.7$ & - \\
\hline $\begin{array}{l}\text { CEC } \\
\text { (méq/100g) }\end{array}$ & $4.7 \pm 0.3$ & $\begin{array}{l}6.36 \pm 2 . \\
2\end{array}$ & $\begin{array}{l}13.03 \pm 0 \\
.3\end{array}$ & $\begin{array}{l}34.59 \pm 28 . \\
1\end{array}$ & $\begin{array}{l}7.91 \pm 4 . \\
6 \\
\end{array}$ & \begin{tabular}{|l|}
15.44 \\
\pm 0.0
\end{tabular} & $8.03 \pm 4.1$ & \begin{tabular}{|l|}
$20.09 \pm 19$. \\
7
\end{tabular} & - \\
\hline
\end{tabular}


Abundance and Diversity of Arbuscular Mycorrhizal Fungi in a Soil Polluted by Mining Activities in Lubumbashi (Haut-Katanga, D.R. Congo)

\begin{tabular}{|c|c|c|c|c|c|c|c|c|c|}
\hline $\begin{array}{l}\mathrm{Ca}^{2+} \\
(\mathbf{m e ́ q} / \mathbf{1 0 0 g})\end{array}$ & $8.84 \pm 7.1$ & $\begin{array}{l}14.36 \pm 1 \\
3.9\end{array}$ & $\begin{array}{l}4.83 \pm 0 . \\
2\end{array}$ & $4.7 \pm 0.1$ & $\begin{array}{l}3.35 \pm 1 . \\
8\end{array}$ & $\begin{array}{l}4.3 \pm 0 . \\
0\end{array}$ & $9.34 \pm 8.2$ & $4.08 \pm 1.1$ & - \\
\hline $\begin{array}{l}\mathrm{Mg}^{2+} \\
(\mathrm{méq} / \mathbf{1 0 0 g})\end{array}$ & $0.8 \pm 0.2$ & $\begin{array}{l}1.76 \pm 0 . \\
5\end{array}$ & $\begin{array}{l}3.28 \pm 1 \\
9\end{array}$ & $1.96 \pm 2.3$ & $1.8 \pm 0.5$ & $\begin{array}{l}3.52 \pm \\
0.0\end{array}$ & $1.95 \pm 1.4$ & $2.21 \pm 1.4$ & - \\
\hline $\begin{array}{l}\mathrm{K}^{+} \\
\text {(méq/100g) }\end{array}$ & $0.73 \pm 0.7$ & $\begin{array}{l}0.65 \pm 0 . \\
6\end{array}$ & $1.3 \pm 0.3$ & $1.25 \pm 0.5$ & $\begin{array}{l}1.06 \pm 0 . \\
9\end{array}$ & $\begin{array}{l}1.6 \pm 0 . \\
0\end{array}$ & $0.89 \pm 0.5$ & $1.24 \pm 0.6$ & - \\
\hline $\begin{array}{l}\mathrm{Na}^{+} \\
(\mathrm{méq} / \mathbf{1 0 0 g})\end{array}$ & $0.06 \pm 0.0$ & $\begin{array}{l}0.04 \pm 0 . \\
0\end{array}$ & $\begin{array}{l}0.08 \pm 0 \\
0\end{array}$ & $0.1 \pm 0.1$ & $\begin{array}{l}0.11 \pm 0 . \\
1\end{array}$ & $\begin{array}{l}0.2 \pm 0 . \\
0\end{array}$ & $0.06 \pm 0.0$ & $0.12 \pm 0.1$ & - \\
\hline$K \operatorname{tot}(\%)$ & $2.08 \pm 0.0$ & $\begin{array}{l}2.36 \pm 0 \\
7\end{array}$ & $\begin{array}{l}2.47 \pm 1 \\
0\end{array}$ & $1.9 \pm 0.5$ & $\begin{array}{l}1.35 \pm 0 . \\
0\end{array}$ & $\begin{array}{l}1.08 \pm \\
0.0\end{array}$ & $2.3 \pm 0.6$ & $1.52 \pm 0.4$ & 2.23 \\
\hline Fe tot $(\%)$ & $3.85 \pm 0.8$ & $\begin{array}{l}4.67 \pm 0 . \\
2\end{array}$ & $\begin{array}{l}4.58 \pm 2 . \\
4\end{array}$ & $4.14 \pm 0.3$ & $\begin{array}{l}4.13 \pm 0 . \\
3\end{array}$ & $\begin{array}{l}4.03 \pm \\
0.0\end{array}$ & $4.36 \pm 1.2$ & $4.11 \pm 0.2$ & 4.90 \\
\hline Ti tot $(\%)$ & $0.46 \pm 0.0$ & $\begin{array}{l}0.48 \pm 0 . \\
1\end{array}$ & $\begin{array}{l}0.48 \pm 0 \\
1\end{array}$ & $0.57 \pm 0.0$ & $\begin{array}{l}0.54 \pm 0 . \\
0\end{array}$ & $\begin{array}{l}0.52 \pm \\
0.0\end{array}$ & $0.47 \pm 0.1$ & $0.55 \pm 0.0$ & - \\
\hline $\begin{array}{l}\text { Cu tot }(\mu \mathrm{g} / \mathrm{g} \\
\text { soil })\end{array}$ & $\begin{array}{l}5633.5 \pm 1 \\
956.6 \\
\end{array}$ & $\begin{array}{l}1230 \pm 5 \\
9.4\end{array}$ & $59 \pm 26.9$ & $\begin{array}{l}1150.5 \pm 1 \\
506.8 \\
\end{array}$ & $\begin{array}{l}511 \pm 0 . \\
0\end{array}$ & ND & $\begin{array}{l}2307.5 \pm 2 \\
770.9\end{array}$ & $\begin{array}{l}937.33 \pm 1 \\
127.7 \\
\end{array}$ & $\begin{array}{l}8591 \\
.50\end{array}$ \\
\hline $\begin{array}{l}\text { Mn tot }(\mu \mathrm{g} / \mathrm{g} \\
\text { soil })\end{array}$ & $521.5 \pm 2.1$ & $\begin{array}{l}318.5 \pm 2 \\
36.9 \\
\end{array}$ & \begin{tabular}{|l}
$441.5 \pm 2$ \\
.1
\end{tabular} & $\begin{array}{l}128.0 \pm 52 . \\
3\end{array}$ & $\begin{array}{l}89.0 \pm 5 \\
7\end{array}$ & $\begin{array}{l}66.0 \pm \\
0.0\end{array}$ & $\begin{array}{l}427.17 \pm 1 \\
40.0\end{array}$ & $\begin{array}{l}100.0 \pm 37 \\
9\end{array}$ & - \\
\hline $\begin{array}{l}\text { Rb tot }(\mu \mathrm{g} / \mathrm{g} \\
\text { soil })\end{array}$ & $83.0 \pm 2.8$ & $\begin{array}{l}92.5 \pm 20 \\
.5\end{array}$ & $\begin{array}{l}96.0 \pm 31 \\
.1\end{array}$ & $89 \pm 4.2$ & $\begin{array}{l}89.5 \pm 6 . \\
4\end{array}$ & $\begin{array}{l}73.0 \pm \\
0.0\end{array}$ & $90.5 \pm 17.8$ & $86.0 \pm 8.2$ & - \\
\hline $\begin{array}{l}\text { Ba tot }(\mu \mathrm{g} / \mathrm{g} \\
\text { soil })\end{array}$ & $\begin{array}{l}499.0 \pm 10 \\
0.4 \\
\end{array}$ & $\begin{array}{l}424.0 \pm 2 \\
5.5\end{array}$ & $\begin{array}{l}386.0 \pm 1 \\
54.1 \\
\end{array}$ & $\begin{array}{l}463.0 \pm 10 \\
4.7\end{array}$ & $\begin{array}{l}327.5 \pm \\
16.3 \\
\end{array}$ & $\begin{array}{l}338.0 \\
\pm 0.0 \\
\end{array}$ & $\begin{array}{l}436.33 \pm 9 \\
7.7\end{array}$ & $\begin{array}{l}383.8 \pm 89 . \\
7\end{array}$ & - \\
\hline
\end{tabular}

ND: not determined at XR-F

\subsection{AMF species abundance}

Figure 3 shows the abundance of AMF species and the evolution of AMF total abundance in both forest and savannah. In the forest (figure 3a) and in the savannah (figure 3b), the abundance of all identified species increases with increasing distance from TP. Therefore, in the forest, no species was observed within $0 \mathrm{~m}$ of TP. This trend is also observed in the savannah with the species Acaulospora lacunosa and Archaospora schenkii, but not observed with Acaulospora scrobiculata, whose abundance is almost similar between points according to the distance to TP in the savannah. As for the evolution of AMF total abundance, the observation shows a great increase following the distance to TP in both forest and savannah. Thus, the low abundances are observed at $0 \mathrm{~m}$ while the high abundances are observed at 400 far from TP (figures $3 \mathrm{c}$ and $\mathrm{d}$ ).

The results of AMF species abundance comparison and AMF total abundance comparison in both ecosystems (forest and savannah), summarized in figure 4, show that the two ecosystems have relatively similar abundances referring to A. scrobiculata and A. schenkii, while A. lacunosa is most abundant (5 spores per $100 \mathrm{~g}$ soil) in the savannah than in the forest ( 3 spores per $100 \mathrm{~g}$ soil). However, AMF total abundance is higher in the savannah than that observed in the forest.

\subsection{AMF species diversity}

Table 2 presents the list and characteristics of AMF species determined in the soils surrounding TP. Thus, three AMF species with different characteristics were identified and two unidentified species. The most represented species are Acaulospora lacunosa with 42 individuals followed by the species Archaospora schenkii with 40 individuals, while the least abundant species is Acaulospora scrobiculata with 24 individuals. Identified species have been differentiated according to their respective dimensions, sizes and colours.

Diversity indices analysis, as summarized in table 3, shows that the highest species number is found at $200 \mathrm{~m}$ and $400 \mathrm{~m}$ in the forest (The highest specific richness), while this number is similar for all points in the savannah. Strong dominance indices are observed at $0 \mathrm{~m}$ followed by $400 \mathrm{~m}$ and $200 \mathrm{~m}$ in the forest and at $200 \mathrm{~m}$ followed by $400 \mathrm{~m}$ and $0 \mathrm{~m}$ in the savannah. The highest Shannon and equitability indices are observed at $200 \mathrm{~m}$ in the forest, while those in the savannah were almost similar. 
Abundance and Diversity of Arbuscular Mycorrhizal Fungi in a Soil Polluted by Mining Activities in Lubumbashi (Haut-Katanga, D.R. Congo)
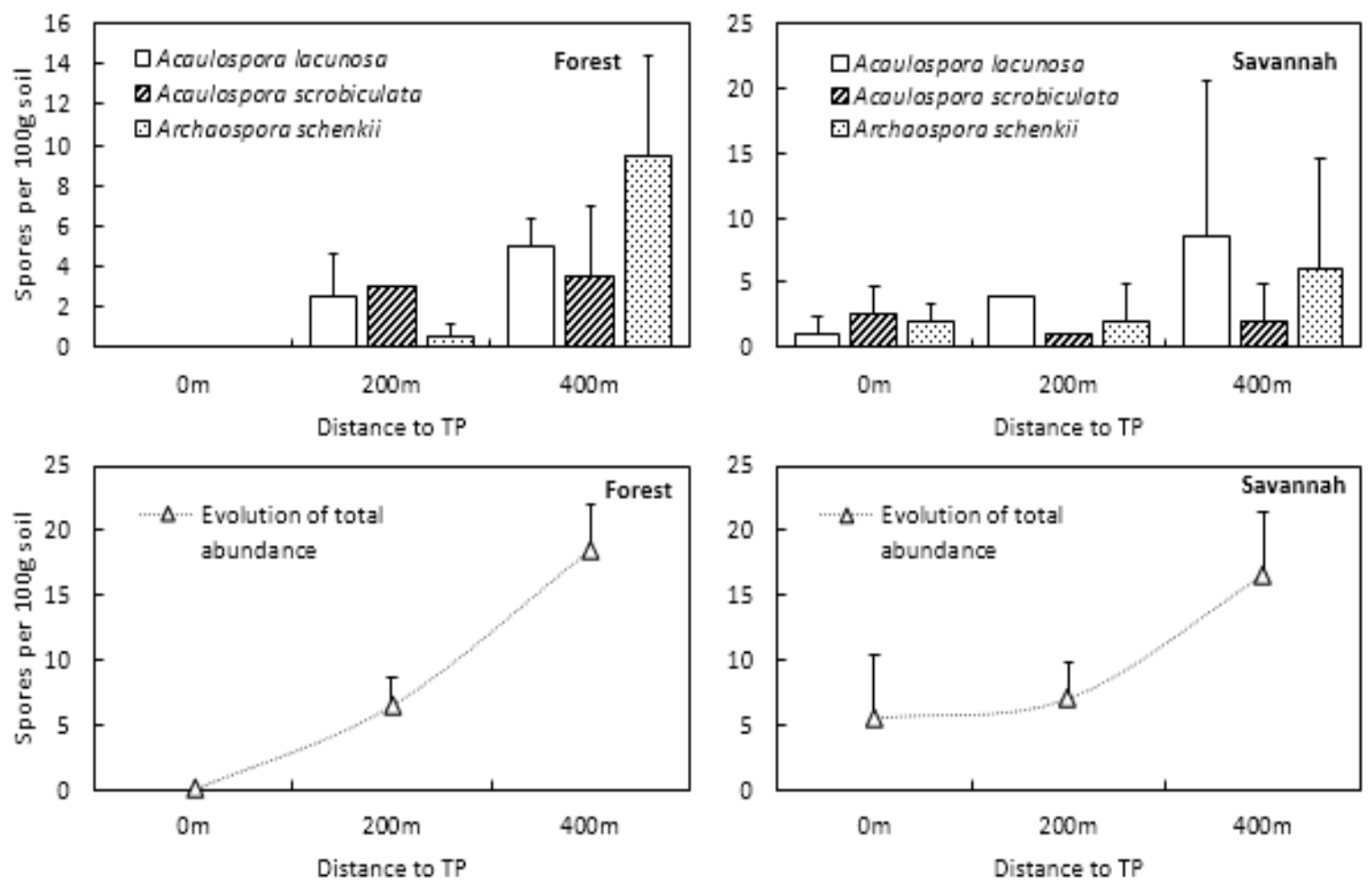

Figure 3. Abundances of AMF species and Evolution of total abundance according to distance to TP within the forest and the savannah.
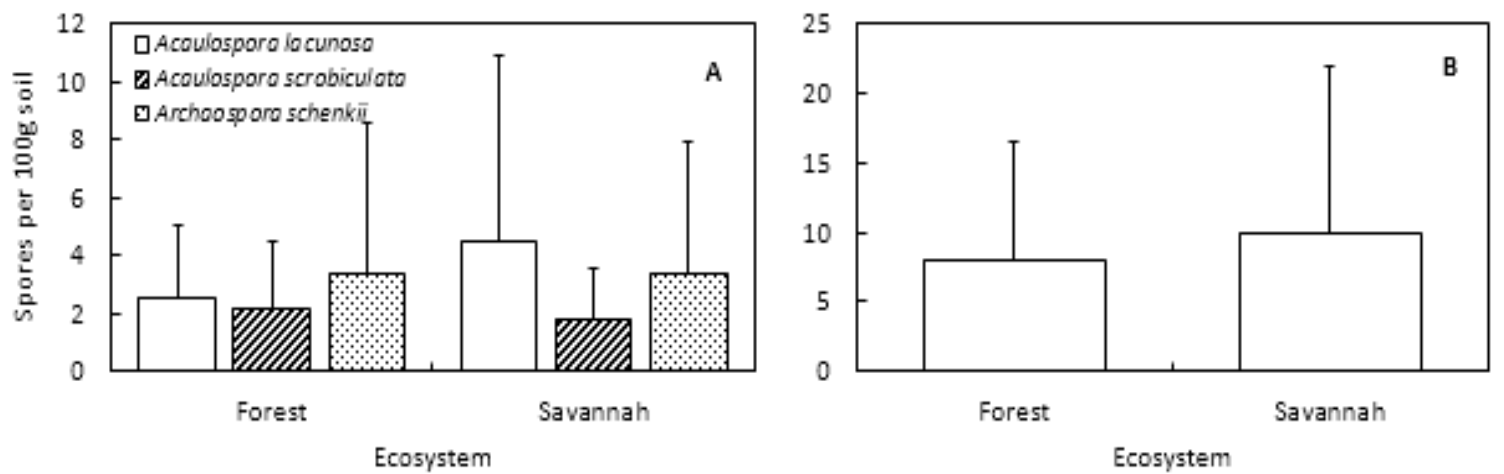

Figure 4. Abundances of AMF species (A) and total abundance (B) within the forest compared to the savannah.

Table2. List and characteristics of AMF species identified in the soils surrounding the TP at MMG / Kinsevere.

\begin{tabular}{|c|c|c|c|c|c|c|}
\hline Family & Genus & Species & Size & Form & Colour & Abundance \\
\hline Archaeosporaceae & Archaospora & A. schenkii & Small & Globose & Colorless & 12 \\
\hline Archaeosporaceae & Archaospora & A. schenkii & Small & Ellipsoid & Colorless & 1 \\
\hline Archaeosporaceae & Archaospora & A. schenkii & Small & Globose & Colorless & 27 \\
\hline Archaeosporaceae & Acaulospora & A. lacunosa & Small & Globose & Brown & 42 \\
\hline Acaulosporaceae & Acaulospora & A. scrobiculata & Small & Peanut & Yellow & 2 \\
\hline Acaulosporaceae & Acaulospora & A. scrobiculata & Small & Ovoid & Yellow & 3 \\
\hline Acaulosporaceae & Acaulospora & A. scrobiculata & Small & Globose & Yellow & 19 \\
\hline- & - & Unidentified & Middle & Globose & Brown & 1 \\
\hline- & - & Unidentified & Middle & Globose & Colorless & 1 \\
\hline Total & $\mathbf{2}$ & $\mathbf{3}$ & $\mathbf{2}$ & $\mathbf{4}$ & $\mathbf{3}$ & $\mathbf{1 0 8}$ \\
\hline
\end{tabular}


Abundance and Diversity of Arbuscular Mycorrhizal Fungi in a Soil Polluted by Mining Activities in Lubumbashi (Haut-Katanga, D.R. Congo)

Table3. Diversity indices of AMF species in both ecosystems (forest and savannah) around the TP at MMG / Kinsevere

\begin{tabular}{|l|l|l|l|}
\hline \multicolumn{4}{|l|}{ Distance to TP } \\
\hline Diversity indices & $0 \mathrm{~m}$ & $200 \mathrm{~m}$ & $400 \mathrm{~m}$ \\
\hline Forest & 1.00 & 4.00 & 4.00 \\
\hline Specific richness (S) & 1.00 & 0.31 & 0.36 \\
\hline Dominance (D) & 0.00 & 1.26 & 1.17 \\
\hline Shannon wiener (H) & - & 0.91 & 0.84 \\
\hline Equitability (J) & \multicolumn{2}{l|}{} \\
\hline Savannah & 3.00 & 3.00 & 3.00 \\
\hline Specific richness (S) & 0.39 & 0.43 & 0.42 \\
\hline Dominance (D) & 1.01 & 0.96 & 0.96 \\
\hline Shannon wiener (H) & 0.92 & 0.87 & 0.87 \\
\hline Equitability (J) &
\end{tabular}

\section{DISCUSSION}

High values of $\mathrm{pH}-\mathrm{H}_{2} \mathrm{O}$ were observed at $400 \mathrm{~m}$ from TP, while those of $\mathrm{pH}-\mathrm{KCl}$ were observed at $0 \mathrm{~m}$ from TP in both ecosystems (table 1). However, the soils surrounding TP (up to $400 \mathrm{~m}$ ) are reported to be slightly acidic in both ecosystems, with an average $\mathrm{pH}-\mathrm{H}_{2} \mathrm{O}$ of 5 and a $\mathrm{pH}-\mathrm{KCl}$ of 4 . This acidity is reported as characteristic of the soils of Lubumbashi and its surroundings (Ngongo et al., 2009). The evolution of $\mathrm{pH}$ would also explain that of CEC, which is intimately linked to it. The results found in this study showed that $\mathrm{Fe}, \mathrm{Cu}, \mathrm{Mn}$ and $\mathrm{Ba}$ concentrations decreased with increasing distance from $\mathrm{TP}$ in both forest and savannah, while those of $\mathrm{Ti}$ and $\mathrm{Rb}$ had a completely different behavior (table 1 ). The average $\mathrm{Cu}$ and $\mathrm{Fe}$ concentrations were significantly higher than those reported as a reference value by Ngoy et al. (2018). These observed anomalies clearly indicate environmental pollution due to mining activities. In both ecosystems, OM was more abundant at $400 \mathrm{~m}$ from TP; this variability along the transects is probably related to the difference in balances between its incorporation through litter and its decomposition by soil organisms (Chadwick and Asner, 2016). The slight decrease in N tot near TP can be explained by the loss of $\mathrm{N}$ in nitrate $\left(\mathrm{NO}^{3-}\right)$ by leaching (Gouyer, 2001; Cattan et al., 2006) and probably by the low OM content.

The abundance of the three identified AMF species increases according to the distance to TP in both forest and savannah (figures $3 \mathrm{a}$ and $\mathrm{b}$ ), except A. scrobiculata, whose abundance is almost similar between the points according to the distance to TP in the savannah. However, the total abundance of AMF increases with distance from TP (figures $3 \mathrm{c}$ and d). These low AMF species abundances near TP can be attributed to the high toxicity of heavy metals to them. The study by Xu et al. (2012), conducted in a mining area, reported negative effects of high concentrations of $\mathrm{Pb}$ and $\mathrm{Zn}$ on mycorrhizal colonization. The results reported in this study are also in agreement with Vogel-Mikuš et al. (2005) who reported that mycorrhizal colonization was weak or absent on plots heavily polluted with heavy metals. Likewise, $\mathrm{Wu}$ et al. (2010) reported that high $\mathrm{As}, \mathrm{Pb}, \mathrm{Zn}, \mathrm{Cd}$ and $\mathrm{Cu}$ concentrations exerted a detrimental effect on AMF spores' number in an abandoned mine. The slowing of mycorrhizal colonization on contaminated soil may in part be due to the high availability of metals caused by low pH (table 1; Kabata-Pendias, 2001), vegetation disturbance and site erosion (Liu et al., 2011). This may justify the high abundance of AMF spores, even near TP in the savannah, compared to the forest in our study (figure 4). Indeed, heavy metals have already been reported responsible for the reduction, delay, or even the elimination of the density of AMF spores on heavy metals polluted sites (Lingua et al., 2008; Wei et al., 2014). However, several other studies have reported positive, negative, or neutral effects of high heavy metals concentrations on mycorrhizal colonization and spore density in mining areas (Khade and Adholeya, 2009; Wu et al., 2010; Yang et al., 2015). This indicates that the effects of heavy metals on AMF may also depend on other environmental factors, in particular the AMF species, the season, the host plant, ... (Pande and Tarafdar, 2004; Ji et al., 2012; Vieira et al., 2018).

In the present study, three AMF species of were identified and one unidentified species in the mine site; Acaulospora lacunosa and Archaospora schenkii were the most dominant (table 2). In comparison, the forest presented a higher specific richness than the savannah (table 3). This variability in specific 
richness, relating to Teixeira et al. (2017), may be explained by the difference between the vegetation (forest and savanna) found around TP; even so close to each other. De Cavalho et al. (2012), studying the different areas of rocky fields belonging to the Cerrado biome, also reported variabilities in the diversity of AMF species among the sampled areas and attributed it to the heterogeneity of the studied habitats. The AMF specific richness values found in the present study were low than that detected in areas affected by mining activities in the United States (Kiernan et al., 1983), India (Raman et al., 1993) and Brazil. (Mergulhão et al., 2010; Teixeira et al., 2017; Vieira et al., 2018). However, the presence of these AMF species in a heavily polluted site can be effective in the ecological restoration of areas degraded by mining activities.

\section{CONCLUSION}

The present study has highlighted the AMF abundance and diversity in a site polluted by mining activities in the Lubumbashi region. The results of the chemical properties showed that heavy metals contents varied from point to point and that $\mathrm{Fe}, \mathrm{Cu}, \mathrm{Mn}, \mathrm{Ba}$, concentrations and of other elements although decreasing with the distance to TP, remained significantly higher than the reference values for unpolluted soils in the study area, demonstrating pollution linked to mining activities. The abundance of different AMF species increased with distance from TP in both forest and savannah, but a few AMF spores were present near TP in the savannah, demonstrating a probable resistance of these species to high metals concentrations. Three species including A. lacunosa, A. schenkii and A. scrobiculata have been identified on the site, thus demonstrating a crucial interest in the restoration of sites degraded by mining activities. It would be interesting in future studies to isolate these AMF species and assess their resistance to different heavy metals concentrations in order to explore their potential in the remediation of polluted areas.

\section{REFERENCES}

[1] Blum W.E. (2005). Functions of soil for society and the environment. Reviews in Environmental Science and Bio/Technology, 4(3), 75-79.

[2] Young I. M., Crawford J.W. (2004). Interactions and self-organization in the soil-microbe complex. Science, 304(5677), 1634-1637.

[3] Lehmann J., Kleber M. (2015). The contentious nature of soil organic matter. Nature 528, 60-68.

[4] Ouedraogo J. Ouedraogo E., Nacro H.B. (2017). La macrofaune du sol améliore l'efficience de l'utilisation de l'énergie par les microorganismes. Journal of Applied Biosciences 114: 11345-11356. https://dx.doi.org/10.4314/jab.v114i1.8

[5] Xu Y., Seshadri B., Bolan N., Sarkar B., Ok Y. S., Zhang W., Rumpel C., Sparks D., Farrell M., Hall T., Dong Z. (2019). Microbial functional diversity and carbon use feedback in soils as affected by heavy metals. Environment International, 125, 478-488. http://doi:10.1016/j.envint.2019.01.071

[6] Konaté S., Le Roux X., Verdier B., Lepage M. (2003). Effect of underground fungus growing termites on carbon dioxide emission on the pointand landscape scales in an African savanna. Functional Ecology, 17: 305-314.

[7] Ouédraogo E., Brussaard L., Mando A., Stroosnijder L., 2005. Organic resources and earthworms affect phosphorus availability to sorghum after phosphate rock addition in semi-arid West Africa. Biolology and Fertility of Soils, 41: 458-465.

[8] Lavelle P., Decaëns T., Aubert M., Barot S., Blouin M., Bureau F., Margerie P., Mora P., Rossi J.P. (2006). Soil invertebrates and ecosystem services. European Journal of Soil Biology, 42: S3-S15.

[9] Pey B. (2010). Contribution de la faune du sol au fonctionnement et à l'évolution des technosols. PhD Thesis Agronomic Sciences, Université Nationale Polytechnique de Lorraine, France, 254 p.

[10] Doamba S.M.F, Nacro H.B, Sanon A., Sedogo M. (2011). Effet des cordons pierreux sur l'activité biologique d'un sol ferrugineux tropical lessivé (Province du Kouritenga au Burkina Faso). International Journal of Biological and Chemical Sciences, 5 (1): 304-313.

[11] Schüßler A., Schwarzott D., Walker C. (2001). A new fungal phylum, the Glomeromycota: phylogeny and evolution. Mycological Research, 105 (12), 1413-1421.

[12] Smith S.E., Read D.J. (2008). Mycorrhizal Symbiosis, third ed. Academic Press, New York, USA, Pp. 1145.

[13] Pellegrino E., Bedini S. (2014). Enhancing ecosystem services in sustainable agriculture: Biofertilization and biofortification of chickpea (Cicer arietinum L.) by arbuscular mycorrhizal fungi. Soil Biology and Biochemistry, 68:429-439. 
[14] Thirkell T.J., Cameron D.D., Hodge A. (2016). Resolving the "nitrogen paradox" of arbuscular mycorrhizas: ertilization with organic matter brings considerable benefits for plant nutrition and growth. Plant, Cell \& Environment, 39(8):1683-1690.

[15] Doubkova P., Suda J., Sudova R. (2012). The symbiosis with arbuscular mycorrhizal fungi contributes to plant tolerance to serpentine edaphic stress. Soil Biology and Biochemistry, 44 (1), 56-64.

[16] Lehmann A., Veresoglou S.D., Leifheit E.F., Rillig M.C. (2014). Arbuscular mycorrhizal influence on zinc nutrition in crop plants-A meta-analysis. Soil Biology and Biochemistry, 69, 123-131.

[17] Cabral L., Soares C.R.F.S., Giachini A.J., Siqueira J.O. (2015). Arbuscular mycorrhizal fungi in phytoremediation of contaminated areas by trace elements: mechanisms and major benefits of their applications. World Journal of Microbiology and Biotechnology, 31(11), 1655-1664.

[18] Cheng Y., Ishimoto K., Kuriyama Y., Osaki M., Ezawa T. (2013). Ninety-year-, but not single, application of phosphorus fertilizer has a major impact on arbuscular mycorrhizal fungal communities. Plant and Soil 365 (1-2), 397-407.

[19] Moebius-Clune D.J., Moebius-Clune B.N., van Es H.M., Pawlowska T.E. (2013). Arbuscular mycorrhizal fungi associated with a single agronomic plant host across the landscape: community differentiation along a soil textural gradient. Soil Biology and Biochemistry, 64, 191-199.

[20] Wang F., Yao J., Si Y., Chena H.L., Russel M., Chena K., Qian Y.G., Zaray G., Bramanti E. (2010). Shorttime effect of heavy metals upon microbial community activity. Journal of Hazardous Materials, 173, 510-516.

[21] Margesin R., Płaza G.A., Kasenbacher S. (2011). Characterization of bacterial communities at heavy-metalcontaminated sites. Chemosphere 82 (11), 1583-1588.

[22] Yang Y., Song Y., Scheller H.V., Ghosh A., Ban Y., Chen H., Tang M. (2015). Community structure of arbuscular mycorrhizal fungi associated with Robinia pseudoacacia in uncontaminated and heavy metal contaminated soils. Soil Biology \& Biochemistry, 1-13.

[23] Gámez-Sagasti M.T., Alkorta I., Becerril J.M., Epelde L., Anza M., Garbisu C. (2012). Microbial monitoring of the recovery of soil quality during heavy metal phytoremediation. Water, Air, \& Soil Pollution, 223 (6), 3249-3262.

[24] Tembo B.D., Sichilongo K., Cernak J. (2005). Distribution of copper, lead, cadmium and zinc concentrations in soils around Kabwe town in Zambia. Chemosphere, 63. 497-501.

[25] Ngoy S.M, Mpundu M.M, Fauconc M-P., Ngongo L.M., Visserd M., Colinet G., Meert P. (2010). Phytostabilisation of Copper-Contaminated Soil in Katanga: An Experiment with Three Native Grasses and Two Amendments. International Journal of Phytoremediation, 12:616-632.

[26] Gremion F, Chatzinotas A, Kaufmann K, Sigler W, Harms H. (2004). Impacts of heavy metal contamination and phytoremediation on a microbial community during a twelve-month microcosm experiment. FEMS Microbiology Ecology, 48, 273-283.

[27] Mpundu M.M., Useni S.Y., Mwamba M.T., Kateta M.G., Mwansa M.E., Ilunga K., Kamengwa K.C. Kyungu K., Nyembo K.L. (2013a). Teneurs en éléments traces métalliques dans les sols de différents jardins potagers de la ville minière de Lubumbashi et risques de contamination des cultures potagères. Journal of Applied Biosciences, 65:4957-4968.

[28] Mpundu M.M., Useni S.Y., Ntumba N.F., Muyambo M.E., Kapangala K.P., Mwansa M.E., Ilunga K., Nyembo K.L. (2013b). Évaluation des teneurs en éléments traces métalliques dans les légumes feuilles vendus dans les différents marchés de la zone minière de Lubumbashi. Journal of Applied Biosciences, 66:5106-5113.

[29] Hall J.L. (2002). Cellular mechanisms for heavy metal detoxification and tolerance. Journal of Experimental Botany, 53, 1-11.

[30] Hassan S.E.D., Boon E., St-Arnaud M., Hijri M. (2011). Molecular biodiversity of arbuscular mycorrhizal fungi in trace metal-polluted soils. Molecular Ecology, 20, 3469-3483. http://doi:10.1111/j.1365294X.2011.05142.x

[31] Bolan N., Kunhikrishnan A., Thangarajan R., Kumpiene J., Park J., Makino T., Kirkham M.B., Scheckel K. (2014). Remediation of heavy metal (loid) s contaminated soils-to mobilize or to immobilize? J. Hazard. Mater. 266, 141-166.

[32] Xing Y., Si Y.X., Hong C., Li Y. (2015). Multiple factors affect diversity and abundance of ammoniaoxidizing microorganisms in iron mine soil. Archives of Environmental Contamination and Toxicology, 69(1), 20-31.

[33] Alguacil M.M., Torrecillas E., Caravaca F., Fernández D.A., Azcón R., Roldán A. (2011). The application of an organic amendment modifies the arbuscular mycorrhizal fungal communities colonizing native seedlings grown in a heavy-metal-polluted soil. Soil Biology and Biochemistry, 43 (7), 1498-1508. 
[34] Mbenza M., Aloni K., Muteb M. (1989). Quelques considerations sur la pollution de l'air à Lubumbashi (Shaba, Zaïre). Géo-eco-trop, 13 (1-4): 113-125.

[35] Lubalega K.T., Ngongo M., Lejoly J., Colinet G. (2015). Contaminations en éléments traces métalliques des termitières autour de Lubumbashi. Congo Sciences, 3(1), 49-55.

[36] Katemo M.B., Clinet G., André L., Chocha M.A. Marquet J-P., Micha J-C. (2010). Les éléments traces (Cu, $\mathrm{Co}, \mathrm{Zn}, \mathrm{Pb}, \mathrm{Cd}, \mathrm{U}, \mathrm{V}$ et As) dans le bassin de la Lufira supérieure (Katanga/RD Congo). TROPICULTURA, 28, 4, 246-252.

[37] Vranken I. (2010). Pollution et contamination des sols aux métaux lourds dues à l'industrie métallurgique à Lubumbashi: Empreinte écologique, impact paysager, pistes de gestion. Université Libre de Bruxelles, 118p.

[38] Ngongo L. M., Van Ranst E., Baert G., Kasongo L. E., Verdoodt A., Mujinya B. B., Mukalay M. J. (2009). Guide des sols en R.D. Congo, Tome I. Etude et gestion. R.D. Congo : UGent, HoGent, UNILU, Lubumbashi, $262 \mathrm{p}$.

[39] Huising J.E., Coe R., Crares J.E., Louzada J.N., Zanetti R., Moreira F.M.S., Susilo F.-X., Konaté S., Van Noordwijk M., Huang S.P. (2012). Sampling stratégyand design to evaluate bolow-ground biodiversity. In Moreira F.M.S., Huising J.E., Bignell D.E. (eds) A hand book of Tropical Soil Biology. Earthscan, USA. Pp. 17-42.

[40] Vannier G., Vidal P. (1964). Construction d'un appareil automatique pour couper les inclusions de sol dans la gélatine. Rev. Ecol. Bio, 1 : sol, 1 : 575-586.

[41] Wang Y., Shi J., Wang H., Lin Q., Chen X., Chen Y. (2007). The influence of soil heavy metals pollution on soil microbial biomass, enzyme activity, and community composition near a copper smelter. Ecotoxicol. Environ. Saf., 67 (1), 75-81.

[42] Zhang C., Shuang N., Liang J., Zeng G., Wu H., Hua S., Liu J., Yuan Y., Xiao H., Deng L., Xiang H. (2016). Effects of heavy metals and soil physicochemical properties on wetland soil microbial biomass and bacterial community structure. Science of the Total Environment, 557-558, 785-790.

[43] Van Ranst E., Verloo M., Demeyer A., Pauwels J.M. (1999). Manual for the soil chemistry and fertility laboratory: analysacal methods for soils and plants equipment, and management of consumables. University of Ghent, Belgium.

[44] Bremner J.M., Mulvaney C.S. (1982). Total nitrogen. In: Page, A.L. (Ed.), Methods of Soil Analysis: Part 2, Agronomy Monograph 9, second ed. American Society of Agronomy and Soil Science Society of America, Madison, Pp. 595-624.

[45] Yoshimura T., Kagemori N., Kawai S., Sera K., Futatsugawa S. (2002). Trace elements in termites by PIXE analysis. Nuclear Instruments and Methods in Physics Research B 189, 450-453.

[46] Samia M., El-Bahi, Amany T., Sroor, Najat F. (2013). Arhoma, Saher M. Darwish, 2013. XRF Analysis of Heavy Metals for Surface Soil of Qarun Lake and Wadi El Rayan in Faiyum. Egypt, Open Journal of Metal, 3, 21-25.

[47] Paulette L., Man T., Weindorf D.C., Personc T. (2015). Rapid assessment of soil and contaminant variability via portable x-ray fluorescence spectroscopy: Copşa Mică, Romania. Geoderma 243-244 (2015) 130-140. http://dx.doi.org/10.1016/j.geoderma.2014.12.025

[48] Walker C., Mize C.W., Mcnabb H.S.JR. (1982). Populations of endogonaceous fungi at two locations in central Iowa. Can. J. Bot. 60: 2518-2529.

[49] Ngoy S.M., Mukobo R.-P., Kaya M.D., Mpundu M.M., Faucon M.-P., Lubalega K.T., Andres L., John A., Vandenheede N., Pourret O., Ngongo L.M., COlinet G. (2018). Fond pédogéochimique et cartographie des pollutions des sols à Lubumbashi. In Bogaert J., Colinet G. \& Mahy G. (eds.). Anthropisation des paysages katangais. Gembloux, Belgique : Presses Universitaires de Liège - Agronomie-Gembloux, Pp. 215-228.

[50] Chadwick K.D., Asner G.P. (2016). Tropical soil nutrient distributions determined by biotic and hillslope processes. Biogeochemistry 127, 273-289. doi:10.1007/s10533-015-0179-Z

[51] Gouyer S. (2001). Evaluation du transport par ruissellement de surface sur andosol. Mémoire de fin d'étude, ISTOM.

[52] Cattan P., Cabidoche Y.M., Lacas J.G., Voltz M. (2006). Effects of tillage and mulching on runoff under banana (Musa spp.) on a tropical Andosol. Soil and Tillage Research, 86(1), 38-51.

[53] Xu Z.Y., Tang M., Chen H., Ban Y.H., Zhang H.H. (2012). Microbial community structure in the rhizosphere of Sophora viciifolia grown at a lead and zinc mine of northwest China. Science of the Total Environment, 435, 453-464.

[54] Vogel-Mikuš K., Drobne D., Regvar M. (2005). Zn, Cd and Pb accumulation and arbuscular mycorrhizal colonisation of pennycress Thlaspi praecox Wulf. (Brassicaceae) from the vicinity of a lead mine and smelter in Slovenia. Environmental Pollution, 133(2), 233-242. 
[55] Wu, F.Y., Bi, Y.L., Leung, H.M., Ye, Z.H., Lin, X.G., Wong, M.H. (2010). Accumulation of As, Pb, Zn, $\mathrm{Cd}$ and $\mathrm{Cu}$ and arbuscular mycorrhizal status in populations of Cynodon dactylon grown on metalcontaminated soils. Applied Soil Ecology, 44 (3), 213-218.

[56] Kabata-Pendias A. (2001). Trace elements in soils and plants. CRC, Bocca Raton, p 413.

[57] Liu Y., He J., Shi G., An L., Öpik, M., Feng, H. (2011). Diverse communities of arbuscular mycorrhizal fungi inhabit sites with very high altitude in Tibet Plateau. FEMS Microbiology Ecology, 78 (2), 355-365.

[58] Lingua G., Franchin C., Todeschini V., Castiglione S., Biondi S., Burlando B., Parravicini V., Torrigiani P., Berta G. (2008). Arbuscular mycorrhizal fungi differentially affect the response to high zinc concentrations of two registered poplar clones. Environmental Pollution, 153 (1), 137-147.

[59] Wei Y., Hou H., Li J., ShangGuan Y., Xu Y., Zhang J., Zhao L., Wang W. (2014). Molecular diversity of arbuscular mycorrhizal fungi associated with an Mn hyperaccumulator-Phytolacca americana, in Mn mining area. Applied Soil Ecology, 82, 11-17.

[60] Khade S.W., Adholeya A. (2009). Arbuscular mycorrhizal association in plants growing on metalcontaminated and noncontaminated soils adjoining Kanpur tanneries, Uttar Pradesh, India. Water, Air, and Soil Pollution, 202 (1-4), 45-56.

[61] Pande M., Tarafdar J.C. (2004). Abuscular mycorrhizal fungal diversity in neem-based agroforestry systems in Rajasthan. Applied Soil Ecology, 26, 233-241.

[62] Ji B., Bentivenga S.P., Casper B.B. (2012). Comparisons of AM fungal spore communities with the same hosts but different soil chemistries over local and geographical scales. Oecologia, 168, 187-197.

[63] Vieira C.K., Marascalchi M.N., Rodrigues A.V., de Armas R.D., Stürmer S.L. (2018). Morphological and molecular diversity of arbuscular mycorrhizal fungi in revegetated iron-mining site has the same magnitude of adjacent pristine ecosystems. Journal of Environmental Sciences, 67, 330-343. http://doi:10.1016/j.jes.2017.08.019

[64] Teixeira A.F. dos S., Kemmelmeier K., Marascalchi M.N., Stürmer S.L., Carneiro M.A.C., Moreira F.M. de S. (2017). Arbuscular mycorrhizal fungal communities in an iron mining area and its surroundings: Inoculum potential, density, and diversity of spores related to soil properties. Ciência e Agrotecnologia, 41(5), 511525. http://doi:10.1590/1413-70542017415014617

[65] De Carvalho F., De Souza F. A., Carrenho R., de Souza Moreira F.M., da Conceicão Jesus E., Fernandes G.W. (2012). The mosaic of habitats in the high-altitude Brazilian rupestrian fields is a hotspot for arbuscular mycorrhizal fungi. Applied Soil Ecology, 52, 9-19.

[66] Kiernan J.M., Hendrix J.W., Maronek D.M. (1983). Endomycorrhizal fungi occurring on orphan strip mines in Kentucky. Canadian Journal of Botany, 61(6):1798-1803.

[67] Raman N., Nagarajan N., Gopinathan S., Sambandan K. (1993). Mycorrhizal status of plant species colonizing a magnesite mine spoil in India. Biology and Fertility of Soils, 16(1), 76-78.

[68] Mergulhão A.C.D.E.S., Burity H.A., Goto B.T., Maia L.C. (2010). Diversity of arbuscular mycorrhizal fungi in a gypsum mining impacted semiarid area. Acta botanica brasilica, 24(4), 1052-1061.

Citation: Mashagiro Grace Queen, et.al., " Abundance and Diversity of Arbuscular Mycorrhizal Fungi in a Soil Polluted by Mining Activities in Lubumbashi (Haut-Katanga, D.R. Congo)", International Journal of Research in Environmental Science (IJRES), vol. 6, no. 4, pp. 1-11, 2020. Available: DOI: http://dx.doi.org/ $10.20431 / 2454-9444.0604001$

Copyright: () 2020 Authors. This is an open-access article distributed under the terms of the Creative Commons Attribution License, which permits unrestricted use, distribution, and reproduction in any medium, provided the original author and source are credited. 